\title{
Hubungan Behavioral Intention (Niat Perilaku) Dengan Perilaku Vandalisme Pada Koleksi Textbook Di UPT Perpustakaan UIN Raden Fatah Palembang
}

\author{
Tika Octaria Bhekti ${ }^{*}$; Bety $^{2}$; Misroni ${ }^{3}$ \\ ${ }^{1}$ Program Studi Ilmu Perpustakaan Fakultas Adab dan Humaniora \\ ${ }^{2}$ Program Studi Ilmu Perpustakaan Fakultas Adab dan Humaniora \\ ${ }^{3}$ Program Studi Ilmu Perpustakaan Fakultas Adab dan Humaniora \\ *Koresponensi: tikaoktaria7@gmail.com
}

\begin{abstract}
This study to explaned the relationship between behavioral intention and vandalism behavior in the textbook collection at the Integrited Library of UIN Raden Fatah Palembang. This research is a quantitative research. Methods of collecting data consist of questionnaires, observation, interviews and documentation. The population of this study is 52.040 visitors of the library and the sample is taken by 100 people. To measure the data likert scala is used and the test used is Pearson Product Moment formula is used for test validity and Cronbach Alpha formula is used for test reliability. Data analysis includes the following steps: 1) Descriptive analysis using the mean and grand mean, 2) Correlation test using Pearson product moment, and 3) Hypothesis test by comparing between $r$-table (0.256) and r-count (0.415), $r$-count obtained from table $r$ on number 100 with an error rate of 10\%. The results showed that the relationship between behavioral intention and vandalism behavior in the textbook collection in Integrited Library of UIN Raden Fatah Palembang was in the high category and there was a positive and moderate relationship between behavioral intention towards vandalism and student vandalism.
\end{abstract}

Keywords: behavioral intention, vandalism behavior

\begin{abstract}
Abstrak
Penelitian ini menjelaskan hubungan antara niat perilaku dan perilaku vandalisme dalam koleksi buku teks di Perpustakaan UIN Raden Fatah Palembang. Penelitian ini adalah penelitian kuantitatif. Metode pengumpulan data terdiri dari kuesioner, observasi, wawancara dan dokumentasi. Populasi penelitian ini adalah 52.040 pengunjung perpustakaan dan sampel diambil oleh 100 orang. Untuk mengukur data likert digunakan skala dan tes yang digunakan adalah rumus Pearson Product Moment digunakan untuk uji validitas dan rumus Cronbach Alpha digunakan untuk uji reliabilitas. Analisis data meliputi langkah-langkah berikut: 1) Analisis deskriptif menggunakan mean dan grand mean, 2) Uji korelasi menggunakan product moment Pearson, dan 3) Uji hipotesis dengan membandingkan antara $r$-tabel $(0,256)$ dan $r$-hitung $(0,415), r$-hitung diperoleh dari tabel $r$ pada nomor 100 dengan tingkat kesalahan 10\%. Hasil penelitian menunjukkan bahwa hubungan antara niat perilaku dan perilaku vandalisme dalam koleksi buku teks di Perpustakaan Terpadu UIN Raden Fatah Palembang berada dalam kategori tinggi dan ada hubungan positif dan moderat antara niat perilaku terhadap vandalisme dan vandalisme siswa.
\end{abstract}

Kata Kunci: niat perilaku, perilaku vandalisme

\section{PENDAHULUAN}

Informasi telah menjadi bagian penting dalam kehidupan sehari-hari, baik dalam suatu pendidikan, pekerjaan dan aspek kehidupan lainnya. Informasi menurut Gordon B. Davis merupakan suatu data yang telah diolah menjadi sebuah bentuk yang berarti bagi penerimanya dan bermanfaat dalam mengambil keputusan saat ini atau mendatang (Ati dkk., 2014). Keberadaan informasi digunakan untuk dapat mengurangi ketidakpastian (reduction of uncertainty). Ketidakpastian informasi dapat memberikan efek negatif terhadap masyarakat yang dapat berdampak pada lenyapnya pengetahuan. Dewasa ini, perkembangan informasi menjadi semakin kuat dengan adanya teknologi digital yang menjadikan informasi sebagai pondasi utama. Pesatnya perkembangan informasi menyebabkan informasi membanjir. 
Tadwin:Jurnal Ilmu Perpustakaan dan Informasi,Vol 1 (1) 2020, Halaman: 44-49

Copyright (O2020

Available Online at: http://jurnal.radenfatah.ac.id/index.php/tadwin

Banjir informasi ditandai dengan informasi mulai bertebaran dan hampir tidak terbatas oleh jarak ruang dan waktu. Informasi-informasi tersebut dapat dengan mudah diperoleh dari berbagai media, baik dalam bentuk tercetak maupun dalam bentuk digital (Septiyantono, 2017). Oleh karena itu, perlu adanya distributor yang tepat agar informasi tersebut dapat diolah dan disalurkan secara tepat kepada para pencari informasi.

Perpusakaan menjadi sebuah solusi yang tepat dalam menangani informasi yang membanjir, salah satunya dengan cara mengorganisasikan informasi. Perpustakaan menjadi sarana penunjang dari sumber yang didapat untuk kemudian menjadi informasi dan pengetahuan. Karena perpustakaan bertugas dalam menghimpun informasi, mengelola, memberdayakan dan memberikan layanan secara optimal (Suwarno, 2009). Dalam menghimpun informasi, meliputi kegiatan mencari dan menyeleksi. Selanjutnya dilakukan pegelolaan yang meliputi proses penyusunan, penyimpanan, pengemasan sehingga mudah dalam temu balik informasi yang dapat menunjang layanan perpustakaan yang baik sekaligus dapat memberdayakan pusat informasi yang menyimpan berbagai ilmu pengetahuan.

Menurut Undang-Undang Republik Indonesia No. 43 Tahun 2007 tentang Perpustakaan, perpustakaan adalah institusi pengelola koleksi karya tulis, karya cetak, dan/atau karya rekam secara profesional dengan sistem yang baku guna memenuhi kebutuhan pendidikan, penelitian, pelestarian, informasi, dan rekreasi para pemustaka (Indonesia, 2007). Dalam hal ini, perpustakaan yang dimaksud ialah perpustakaan perguruan tinggi.

Kehadiran perpustakaan perguruan tinggi sangatlah diperlukan dangan tujuan perpustakaan dapat memberikan pelayanan informasi bagi civitas akademika di dalamnya, di antaranya adalah mahasiswa, dosen, karyawan/staf dan peneliti (Rahmawati, 2014). Perpustakaan sebagai sumber informasi mengendalikan peranan penting dalam pembangunan nasional dan menjadi sarana pendukung dalam pendidikan. Sebagai pusat sumber daya informasi perpustakaan menjadi tulang punggung gerak majunya suatu institusi. Informasi-informasi yang tersaji dalam perpustakaan tersimpan dalam suatu bahan pustaka yang disebut koleksi.

Koleksi bagi sebuah perpustakaan merupakan salah satu faktor yang sangat penting guna menjamin ketersediaan layanan yang baik. Koleksi menjadi modal utama, dimana koleski merupakan produk informasi yang akan dijual kepada pengguna, apabila produk tersebut tidak sesuai dengan kebutuhan para pelanggan, sudah tentu para pelanggan perlahanlahan akan meninggalkan dan tidak memanfaatkannya (Listiyani, 2010).

Jumlah koleksi perpustakaan yang semakin meningkat serta berbagai macam aturan yang ditetapkan terhadap pemustaka dapat menyebabkan suatu perilaku yang menyimpang, salah satunya dalam memanfaatkan koleksi perpustakaan. Perilaku menyimpang tersebut disebabkan karena adanya dorongan dalam diri individu. Dorongan tersebut dapat dikatakan sabagai behavioral intention (niat perilaku).

Behavioral intention (niat perilaku) merupakan suatu niat. Niat adalah intensi (intention) adalah keinginan untuk melakukan perilaku. Niat belum berupa perilakunya. Perilaku (behavior) adalah kegiatan atau tindakan nyata yang dilakukan (Jogiyanto, 2008).

Behavioral intention ialah suatu perilaku nyata yang tampak dan dapat diukur secara objektif yang dipandang melalui perbuatan dan tingkah laku manusia (Alhamdu \& Hamdana, 2017). Dengan kata lain behavioral intention merupakan hasil pengamatan terhadap suatu 
Tadwin:Jurnal Ilmu Perpustakaan dan Informasi,Vol 1 (1) 2020, Halaman: 44-49

Copyright (O2020

Available Online at: http://jurnal.radenfatah.ac.id/index.php/tadwin

perilaku, yang mana dari perilaku tersebut akan menghubungkan diri dengan tindakan yang akan datang. Dalam hal ini behavioral intention memiliki keterkaitan antara pemustaka dengan koleksi.

Terdapat perumpamaan antara pemustaka dan koleksi, pemustaka dapat bertindak sebagai lawan atau juga kawan dalam usaha pelestarian bahan pustaka. Sulistyo Basuki menjelaskan bahwa: Manusia dalam hal ini pemakai perpustakaan dapat merupakan lawan atau juga kawan. Pengguna perpustakaan menjadi kawan bilamana dia membantu pengamanan buku dengan cara menggunakan bahan pustaka secara cermat dan hati-hati. Akan tetapi pengguna perpustakaan akan menjadi lawan bilamana dia memperlakukan buku dengan kasar, sehingga sobek atau rusak (Listiyani, 2010). Tindakan pemustaka yang menjadikan koleksi sebagai lawan dapat dikatakan sebagai perilaku vandalisme.

Vandalisme adalah kerusakan pada koleksi perpustakaan, perabot, atau fasilitas perpustakaan yang dilakukan dengan sengaja, dan biasanya dimotivasi oleh kemarahan atau kebencian dari pelaku (Rahmawati, 2014). Tindakan-tindakan perusakan terhadap koleksi perpustakaan yang disebabkan oleh perilaku vandalisme seperti mencoret-coret pada kalimatkalimat penting, melipat lembar buku, menyobek lembar halaman pada buku dan bahkan sampai ada yang menghilangkan buku perpustakaan secara sengaja.

Tindakan vandalisme dapat terjadi bila adanya peluang, seperti sistem layanan perpustakaan yang bersifat terbuka. Di mana pengguna memiliki akses langsung terhadap koleksi perpustakaan. Kemudahan akses yang diberikan kepada pengguna untuk menemukan bahan pustaka yang relevan dan sesuai dengan kebutuhan informasinya melalui sistem layanan terbuka, bisa menjadi celah bagi pengguna yang tak bertanggung jawab untuk melakukan penyalahgunaan koleksi perpustakaan (Efriza, 2015).

Selain itu, pelayanan di perpustakaan yang tidak memuaskan juga dapat mempengaruhi kondisi psikologis seseorang untuk melakukan tindakan vandalisme seperti, kurangnya jam buka, ketidakpedulian pustakawan terhadap kebingungan pemustaka dalam mencari koleksi, dan dapat pula disebabkan dari tuntutan akademik.

Sebagaimana pada UPT Perpustakaan UIN Raden Fatah Palembang, terdapat koleksi perpustakaan yang dicoret-coret pada bagian jarak antara tepi pengetikan dengan tepi halaman pada kertas, kalimat-kalimat penting yang digaris bawahi, dilipat lembar bukunya dan lain sebagainya. Dimana koleksi yang menjadi sasaran vandalisme ialah koleksi textbook yang lebih berfokus pada koleksi sirkulasi. Perilaku vandalisme yang demikian dapat menyebabkan kerugian bagi perpustakaan. Seperti terhalangnya transfer informasi, biaya preservasi bahan pustaka yang mengingkat, menghilangkan keindahan koleksi serta dampak pada lingkungan sosial yang dapat menularkan kebiasaan perilaku vandalisme kepada orang lain.

Berdasarkan masalah tersebut peneliti menentukan tujuan penelitian sebagai berikut: 1 . Mengetahui tingkat hubungan antara behavioral intention dengan perilaku vandalisme pada koleksi textbook di UPT Perpustakaan UIN Raden Fatah Palembang.

2. Mengetahui bagaimana hubungan antara behavioral intention dengan perilaku vandalisme pada koleksi textbook di UPT Perpustakaan UIN Raden Fatah Palembang. 


\section{METODE PENELITIAN}

Pendekatan yang digunakan dalam penelitian ini adalah pendekatan kuantitatif. Metode yang digunakan dalam penelitian ini adalah metode penelitian korelasi. Adapun dalam menganalisa data dengan menggunakan rumus korelasi product moment. Populasi dalam penelitian ini diambil dari jumlah anggota yang berkunjung ke UPT Perpustakaan UIN Raden Fatah Palembang selama satu tahun dari bulan Januari 2017-Desember 2017 sebanyak 52.040. besaran sampel ditentukan dengan menggunakan rumus Slovin yang dikemukakan oleh Husein Umar sehingga diperoleh hasil sebanyak 99,86 yang dibulatkan menjadi 100 pengunjung perpustakaan. Teknik sampling yang digunakan peneliti adalah teknik probbability sampling dengan metode simple random sampling. Penentuan sampel bersifat dinamis, artinya tidak sama sampelnya setiap hari akan tetapi masih ditempat penelitian yang sama yaitu di ruang sirkulasi perpustakaan UIN Raden Fatah Palembang. Teknik pengumpulan data diantaranya: 1) Observasi (pengamatan), 2) Wawancara (interviu), 3) Kuesioner (angket), 4) Dokumentasi.

\section{HASIL DAN PEMBAHASAN}

Berdasarkan permasalahan yang diteliti, didapati hasil temuan pertama yang membahas mengenai seberapa tinggi tingkat hubungan antara behavioral intention (niat perilaku) dengan perilaku vandalisme pada koleksi textbook di UPT Perpustakaan UIN Raden Fatah Palembang, hasil temuan menyatakan bahwa dari hasil setiap butir pernyataan lalu dapat diketahui analisis dari setiap indikator masing-masing variabel, yaitu variabel behavioral intention dan variabel perilaku vandalisme. Dari hasil analisis indikator variabel behavioral intention berisi 11 pernyataandiperoleh nilai sebesar 31,34 . Maka 31,34/11=2,84.Sedangkan untuk hasil analisis indikator variabel perilaku vandalisme berisi 9 pernyataan diperoleh nilai sebesar 26,97. Maka $26,97 / 9=2,99$. Berdasarkan hasil perolehan masing-masing variabel diperoleh total rata-rata $31,34+26,97=58,31 / 20=2,91$. Hasil temuan menunjukkan bahwa hubungan antara behavioral intention dengan perilaku vandalisme pada koleksi textbook di UPT Perpustakaan UIN Raden Fatah Palembang berada pada kriteria penilaian 2,51-3,25 yang dikategorikan memiliki tingkat hubungan yang tinggi.

Sedangkan untuk hasil temuan kedua yang membahas bagaimana hubungan antara behavioral intention(niat perilaku) dengan perilaku vandalisme pada koleksi textbook di UPT Perpustakaan UIN Raden Fatah Palembang didapati hasil seperti berikut: Dari data kuesioner maka diketahui nilai $r_{x y}$ sebesar 0,415 , selanjutnya dilakukan pengujian hipotesis dengan

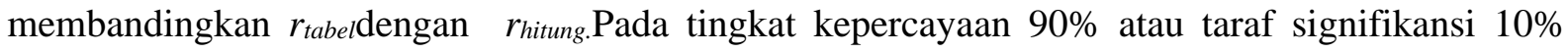
$(0,1)$ diperoleh nilai $\mathrm{r}$ Product Moment pada tabel sebesar 0,256.Dengan begitu diketahui rhitung $>$ $r_{\text {tabel }}(0,415>0,256)$, maka hipotesis dari $H_{0}$ ditolak dan hipotesis $H_{a}$ diterima.Untuk mengetahui interpretasi tinggi rendahnya hubungan antara behavioral intention pemustaka terhadap koleksi textbook dengan perilaku vandalisme di UPT Perpustakaan UIN Raden Fatah Palembang dapat dilihat pada pedoman interpretasi koefisien korelasi berikut:

\begin{tabular}{|c|c|c|}
\hline No. & Interval Koefisien & Tingkat Hubungan \\
\hline 1. & $0,00-0,199$ & Sangat Rendah \\
\hline 2. & $0,20-0,399$ & Rendah \\
\hline
\end{tabular}


Tadwin:Jurnal Ilmu Perpustakaan dan Informasi, Vol 1 (1) 2020, Halaman: 44-49 Copyright (C2020

Available Online at: http://jurnal.radenfatah.ac.id/index.php/tadwin

\begin{tabular}{|c|c|c|}
\hline 3. & $0,40-0,599$ & Sedang \\
\hline 4. & $0,60-0,799$ & Kuat \\
\hline 5. & $0,80-1,000$ & Sangat Kuat \\
\hline
\end{tabular}

Tabel. Pedoman Interpretasi Koefisien Korelasi

Berdasarkan tabel interpretasi di atas dapat disimpulkan bahwa terdapat hubungan yang sedang antara behavioral intention pemustaka terhadap koleksi textbook dengan perilaku vandalisme di UPT Perpustakaan UIN Raden Fatah Palembang.

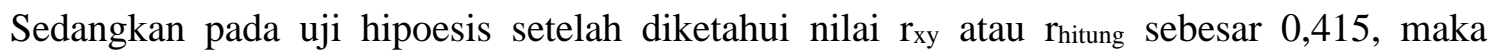
langkah selanjutnya dilakukan pengujian hipotesis terhadap kedua variabel dan membuat interpretasi terhadap $\mathrm{r}_{\mathrm{xy}}$. Pengujian hipotesis menggunakan cara membandingkan nilai $\mathrm{r}_{\text {hitung }}$ dengan $r_{\text {tabel }}$ yaitu membandingkan signifikansi korelasi pada tingkat kepercayaan $90 \%$ atau taraf signifikansi 10\% (0,1). Maka diperoleh nilai r Product Moment pada tabel sebesar 0,256.

Dengan begitu diketahui $\mathrm{r}_{\text {hitung }}>\mathrm{r}_{\text {tabel }}(0,415>0,256)$, maka ditetapkan hipotesis dari $\mathrm{H}_{0}$ ditolak dan hipotesis $\mathrm{H}_{\mathrm{a}}$ diterima. Jadi, dapat disimpulkan bahwa terdapat atau ada hubungan yang signifikan antara behavioral intention pemustaka terhadap koleksi textbook dengan perilaku vandalisme di UPT Perpustakaan UIN Raden Fatah Palembang.

Adapun untuk mengetahui interpretasi tinggi rendahnya hubungan antara behavioral intention pemustaka terhadap koleksi textbook dengan perilaku vandalisme di UPT Perpustakaan UIN Raden Fatah Palembang dapat dilihat pada pedoman interpretasi koefisien korelasi berikut:

Tabel 4.33 Pedoman Interpretasi Koefisien Korelasi

\begin{tabular}{|c|c|c|}
\hline No & Interval Koefisien & Tingkat Hubungan \\
\hline 1. & $0,00-0,199$ & Sangat Rendah \\
\hline 2. & $0,20-0,399$ & Rendah \\
\hline 3. & $0,40-0,599$ & Sedang \\
\hline 4. & $0,60-0,799$ & Kuat \\
\hline 5. & $0,80-1,000$ & Sangat Kuat \\
\hline
\end{tabular}

Berdasarkan tabel interpretasi di atas dapat disimpulkan bahwa terdapat hubungan yang sedang antara behavioral intention pemustaka terhadap koleksi textbook dengan perilaku vandalisme di UPT Perpustakaan UIN Raden Fatah Palembang.

Dari hasil temuan di atas dinyatakan bahwa interpretasi antara behavioral intention dengan perilaku vandalisme pada koleksi textbook di UPT Perpustakaan UIN Raden Fatah Palembang terdapat hubungan yang sedang. Jika dilihat dari teori perilaku rencana (theory of reasoned action) yang menyatakan bahwa perilaku dilakukan karena individu memiliki niat atau keinginan untuk melakukannya yang terdiri dari tiga komponen, yaitu: sikap terhadap perilaku, norma-norma subjektif, 
Tadwin:Jurnal Ilmu Perpustakaan dan Informasi, Vol 1 (1) 2020, Halaman: 44-49

Copyright $@ 2020$

Available Online at: http://jurnal.radenfatah.ac.id/index.php/tadwin

dan kontrol perilaku persepsian maka dapat disimpulkan terdapat keselarasan antara hasil temuan dan teori perilaku rencana (theory of reasoned action).

\section{SIMPULAN}

Berdasarkan analisis data peneliian yang berjudul "Hubungan Behavioral Intention Dengan Perilaku Vandalisme Pada Koleksi Textbook di UPT Perpustakaan UIN Raden Fatah Palembang." Maka dapat disimpulkan beberapa hal, yaitu:

1. Dari analisis deskriptif diketahui bahwa tingkat hubungan antara behavioral intention dan perilaku vandalisme mahasiswa di UPT Perpustakaan UIN Raden Fatah Palembang berada pada kategori tinggi.

2. Terdapat hubungan yang positif dan kuat antara behavioral intention terhadap tindakan vandalisme di UPT Perpustakaan UIN Raden Fatah Palembang dan perilaku vandalisme mahasiswa di UPT Perpustakaan UIN Raden Fatah Palembang.

\section{DAFTAR PUSTAKA}

Alhamdu, \& Hamdana, F. (2017). Psikologi Umum: Pengantar Memahami Manusia. Noer Fikri Offset.

Ati, S., Nurdien H., K., \& Amin, T. (2014). Dasar-Dasar Informasi. Universitas Terbuka.

Efriza, E. (2015). Strategi Managemen Perpustakaan Dalam Menghadapi Vandalisme. Kajian Informasi dan Perpustakaan, Vol. 3, No. 1.

Indonesia. (2007). Undang-undang Perpustakaan No. 43 Tahun 2007. Perpustakaan Nasional RI.

Jogiyanto, H. M. (2008). Sistem Informasi Keperilakuan (Edisi Kedua). ANDI Offset.

Listiyani. (2010). Penyalahgunaan Koleksi Perpustakaan: Studi Kasus Di Perpustakaan Umum Yayasan LIA Pramuka [Skripsi]. Fakultas Ilmu Pengetahuan Budaya, Universitas Indonesia.

Rahmawati, G. N. (2014). Perilaku Vandalisme Pemustaka Di Pusat Perpustakaan Universitas Islam Negeri (UIN) Syarif Hidayatullah [Skripsi]. Fakultas Adab dan Humaniora, Universitas Indonesia Negeri Syarif Hidayatullah.

Septiyantono, T. (2017). Literasi Informasi. Universitas Terbuka.

Suwarno, W. (2009). Psikologi Perpustakaan. Sagung Seto. 